\title{
Mechanism for Imposing Administrative Sanctions for Communities living in forest areas after the Enforcement of the Job Creation Act
}

\author{
I Gusti Ayu Ketut Rachmi Handayani ${ }^{1}$, Lego Karjoko ${ }^{2}$, Abdul Kadir Jaelani ${ }^{3}$ Hilaire Tegnan ${ }^{4}$ Willy Naresta Hanum ${ }^{5}$ \\ ${ }^{1.2 .3 .5}$ Faculty of Law, Universitas Sebelas Maret, Surakarta, Indonesia \\ ${ }^{4}$ Faculty of Law, William \& Mary USA \\ ayu_igk@staff.uns.ac.id
}

\begin{abstract}
The government and the House of Representatives have ratified Law Number 11 concerning Job Creation for the Year 2020; the regulation aims to simplify and harmonize laws and regulations, as well as increase investment in Indonesia; however, an important question that must be addressed is whether the rule's content can provide justice and benefits to people living in forest areas. The purpose of this research is to mechanism for imposing administrative sanctions for communities living in forest areas after the enforcement of the job creation act. The study's findings suggest that the government should ensure that the provisions of Articles $110 \mathrm{~A}$ and 110B are implemented correctly, namely for the benefit of the community in forest areas, by collecting adequate data and preparing data-based implementing regulations, as well as restoring the goals and functions of administrative sanctions that do not require judicial intervention. Administrative punishments are required for environmental restoration as part of the government's rehabilitation coercion. This administrative sanction can be used for both Article 110A and 110B offenses.
\end{abstract}

Keywords-Restoring, Environmental, Adminisrative Sanctions.

\section{INTRODUCTION}

The Government and the House of Representatives have ratified the Job Creation Bill, which consolidates 79 laws and regulations into a single rule, with 15 chapters, 174 articles, and 11 clusters, some of which contain 1,203 articles. Under the guise of creating new job possibilities, this bill intends to enable investment inflows. Omnibus Law is the name of this regulation. The term "omnibus law" refers to a way of combining several laws and regulations into one.[1]

Environmental and forestry issues are addressed in one of the simplified materials. The material for the sector's regulation drew a variety of responses, given the presence of contentious articles such as requirements for the repeal, alteration, and formulation of new company licensing standards as governed in Law Number 32 of 2009 concerning Environmental Protection and Management (UU PPLH). The provision of environmental impact analyses is one of the topics under the focus (Amdal).[2]

There are around 4 (four) difficulties in the Copyright Act relating to the medal provisions being altered, the first of which is the use of the Amdal. The EIA prepared by a certified initiator (the Amdal compiler) is used as the foundation for an environmental feasibility test in the development of a business and activity under the Job Creation Act. A team assembled by the central government's environmental feasibility test agency conducts the environmental feasibility test.[3]

Second, the Law Number 11 Year 2020 concerning Job Creation modifies Article 25 letter c's requirements for the files that must be included in the Amdal document. One of the requirements of the updated agreement is that the community submit recommendations, inputs, and responses. One of the EIA documents must include recommendations for information and answers from the directly impacted community related to the business/activity plan, according to the PPLH Law.[4]

Simultaneously, the Job Creation Act requires the community to make proposals for input and responses (not necessarily the people directly affected). Third, both the Job Creation Act and the PPLH Law regulate community input in the preparation of the Amdal. Job Creation Act, on the other hand, narrows the notion of community.[5] The PPLH Law refers to the affected community, environmentalists, and individuals who are impacted by all types of decisions made during the EIA process. The Job Creation Act solely refers to the persons who are directly affected by the law. Changes to the method for filing Amdal objections. The PPLH Law allows people who disagree with the Amdal document to make a complaint or take legal action, but the Job Creation Act does not provide an Amdal objection procedure.[6] The Job Creation Act repeals the regulations governing the objection mechanism, particularly, the requirements governing the EIA assessment commission, which are governed by the PPLH Law's Articles 29, 30, and 31. The lack of this objection process has aroused criticism in the community because it is thought to be critical in ensuring environmental sustainability, particularly in ensuring that the Amdal document is not drafted hastily or as a formality.[7]

Apart from environmental concerns, there is also the issue of how to impose administrative sanctions on those who live in forest areas. Articles 110A and 110B of Law Number 11 of 2020 Concerning Job Creation contain these requirements.[8] There are several notes in the policy that should be considered. First, the debate over forest amnesty or related issues overlooks the fact that 
forests should be viewed as more than just a resource to be exploited, since there are several environmental externalities to consider.[9] Second, progress is being made in forest areas of various typologies. Aside from differences in landscape context, the reasons of such delays, such as policy disagreements and deliberate forest logging, must be addressed differently. Third, there is the issue of recognizing forest-dependent communities' management rights in the face of corporate breaches. The focus of policy should be on bolstering community management rights and resolving tenure disputes. Fourth, the need for legal certainty should be used to justify the government's refusal to take administrative action in areas where policies overlap before harmonization.[10]

Many environmental permits are contested in state administrative courts, according to the indexation results of 164 TUN decisions conducted by the Institute for the Study and Advocacy of Judicial Independence (LeIP). Thirty of the 164 decisions are related to environmental permit disputes. There were 164 decisions that put EIA to the test, particularly community involvement. The Panel of Judges considered the existence of communal features in the Amdal commission in decision $580 \mathrm{~K} / \mathrm{TUN} / 2018$. It was also discovered to be linked to large-scale government actions that have an environmental impact, specifically decision number: 039/G.PLW/2017/ PTUN.Smg.[11]

The court concluded that mining and drilling above the Groundwater Basin (CAT) were not justifiable in principle. However, according to the panel of judges, it can be excluded with extremely stringent restrictions in specific and measured ways so as not to disrupt the aquifer system for the sake of the nation's and state's vital strategic interests. The approval of the official who decides the status of the region shall accompany the determination of the Environmental Permit. The agreement serves as a policy, as well as an environmental and development policy, as well as the urgency of the nation's and state's interests.[12]

\section{FINDINGS AND DISCUSSION}

All business activities within the forest area must have a business license in the forestry sector, approval from the Minister, cooperation, or partnership, according to the development policy in the forestry sector. in order to optimize the role and function of the forest in supporting sustainable development and maintaining the ecological function of the forest as a life support, all business activities must have a business license in the forestry sector, approval from the Minister, cooperation, or partnership. It is fairly uncommon to come across company activity in the Forest Area that do not have the required permit.[13]

According to the findings, there are oil palm plantations in the Forest Area of +3.3 million hectares that lack legal certainty. Oil palm plantations are held by companies and communities that deserve legal certainty that is fair, dignified, and comprehensive.[14] This is done to provide legal certainty about the existence of nonforestry activity in the Forest Area. Mining, plantation, and other operations such as oil and gas, geothermal, ponds, agriculture, settlements, nature tourism, industry, and $\mathrm{f}$ or amenities and infrastructure are examples of economic activities in Forest Areas that do not have permits in the forestry sector.[15]

The application of the ultimum remedium principle, namely prioritizing the imposition of Administrative Sanctions before being subjected to criminal sanctions for violations that are administrative in nature and do not cause health, safety, or environmental impacts, has resulted in new policy breakthroughs.[16] The ultimum remidium principle is reflected in the regulation of the norms of Article 110A and Article 110B of Law Number 18 Year 2003 concerning the Prevention and Eradication of Forest Destruction, as amended by Article 37 of Law Number 11 Year 2020 concerning Job Creation, particularly Article 110A, which applies to activities that have a business license but do not have a permit in the forest.[17]

The application of Administrative Sanctions and NonTax State Revenue (PNBP) derived from administrative penalties in the forestry sector is also governed by this Government Regulation. The regulatory norm's substance consists of an inventory of data and information on business activities built in a forest region that does not have a forestry sector permit, processes for settling oil palm plantation business operations built in a forest area that has a location permit, and a permit.[18] processes for imposing Administrative Sanctions on commercial activities in a forest region that do not have a permit in the forestry sector, procedures for computing administrative fines, PNBP resulting from administrative penalties, and government coercion This Government Regulation was prepared in the context of completing business activities in Forest Areas prior to the issuance of Law Number 11 Year 202O concerning Job Creation in the Forestry Sector without a Permit, with the goal of providing legal certainty to the community, ensuring business certainty, and legally maintaining the existence of Forests. Maintaining environmental functions, optimizing economic and social benefits, enhancing local communities' economic resilience, and raising state income are all priorities.[19]

The Government Regulation regulates the mechanism for settling business activities in Forest Areas that do not have permits in the forestry sector before Law Number 11 Year 2020 concerning Job Creation applies to oil palm plantation business activities that have been built, have a Location Permit and/or business license in the $p$ Administrative sanctions in the form of administrative fines can be a model for resolving corporate activities in forest regions that do not have forestry permits, which is now one of the major issues in forest area management.[20]

The Government Regulation regulates the procedures and mechanisms of government coercion in the form of blocking, prevention of going abroad, asset confiscation, and forcible agency (gijzelling) for Everyone who does not implement Administrative Sanctions in the form of payment of Administrative Fines to support the 
executorial effect of the imposition of Administrative Sanctions in the form of payment of Administrative Fines.[21]

The Government has prepared a Draft Government Regulation concerning Procedures for Imposing Administrative Sanctions and Procedures for Non-Tax State Revenues Derived from Administrative Fines for Business Activities Built in the Forest Area as a follow-up to Articles 110A and 110B of Law 18/2013 as amended in the Job Creation Law. This RPP governs how business activities are completed, how administrative fines are calculated, and how PNPB is protected against administrative fines and government coercion. Furthermore, this RPP includes a new category for strategic and unavoidable operations. The Minister revokes Administrative Sanctions and gives Approval for Use of Forest Areas for strategic and unavoidable operations that have permits in their fields located in Protected Forest Areas and where Business Actors have paid Administrative Fines as referred to in Article 23 paragraph (3). This is distinct from the requirement to return for non-strategic projects such as Business Activities. In terms of the time period after the field's Business Licensing. Oil and gas, geothermal, infrastructure for public and/or strategic interests, and/or mining activities as defined by Presidential Decree No. 41 of 2004 on Permits or Agreements in the Mining Sector Located in Forest Areas.[22]

In terms of the progress settlement based on Article $110 A$ of the RPP for the Imposition of Administrative Sanctions and Procedures for Non-Tax State Revenue Deriving from Administrative Fines for Business Activities Already in Place, Settlement in Production Forest Areas, Protected Forest Areas, and Conservation Forest Areas are divided into three groups with their own set of regulations. Individuals and businesses who do business in forest areas without a forestry permission prior to the enactment of Law 11/2020 face administrative sanctions such as temporary suspension of operations, administrative fines, and government pressure. It should be highlighted that the provisions of Article 18 paragraph (1) are extremely vague and do not correspond to the title of the chapter of this provision or the legislators' goals. Business activities in the forestry industry that do not require a permit have previously been controlled, and they are the implementers of Article 110A. This research is based on the systematic settlement of the past regulated since Law 11/2020, which refers to Company Actors who do not have permits in the forestry sector and business permits prior to the Job Creation Act in Article 18.[23]

The business activities in the Forest Area are carried out by individuals residing in and/or around the Forest Area for a minimum of five years and continuously with an area of no more than five hectares, they are exempt from Administrative Sanctions and resolved through Forest Area arrangement (social forestry).[24] Furthermore,[25] the Minister will determine the status of the violation based on data from the identification of Business Activities/self-initiated reports from Business Actors, which will include at least the period of violation, the area of the Forest Area controlled, and the calculation of the amount of Administrative Fines. Depending on the severity of the breach, administrative sanctions such as temporary suspension of business operations, orders for payment of administrative fines, and orders for additional licensing arrangements may be applied.[14]

The Minister revokes the Administrative Sanctions and issues an Approval for the Use of Forest Areas for those located in Production Forest Areas, and requires Business Actors to return their Business Activities land to the State for those located in Protected Forest Areas and/or Conservation Forests if the Administrative Sanctions have been implemented. For oil palm plantations, the Approval for the Use of Forest Areas is granted for a maximum of 25 years from the planting period, but for other fields, it is adjusted to its own arrangement. The Applicant is obligated to pay PNBP in the forestry industry under this agreement. Business actors who have obtained Approval for the Use of Forest Areas in Production Forest Areas but whose business activities are in the area of Forest Utilization Permits will have this completed through a cooperation mechanism with the permit holder and subject to payment of PNBP in the forestry sector.[26]

The Minister revokes Administrative Sanctions and gives Approval for Use of Forest Areas for strategic and unavoidable operations that have permits in their fields located in Protected Forest Areas and where Business Actors have paid Administrative Fines as referred to in Article 23 paragraph (3). This is distinct from the requirement to repay for business actions that are not strategic in nature. According to Presidential Decree $41 / 2004$, the term for participating in Business Licensing in their respective domains includes oil and gas, geothermal, infrastructure for public and/or strategic interests, and/or mining activities. The application will be submitted to administrative sanctions before being approved by the Minister for activities and/or businesses that have a business license but do not have a permit in the forestry sector. The payment of the Reforestation Fund (DR) and the provision of forest resources are the administrative fines imposed (PSDH). It's difficult to classify DR and PSDH as administrative sanctions because they're both responsibilities, not responses to noncompliance.[27]

Permit holders must pay DR and PSDH payments to use protected forests and production forests, whether in the form of forest area utilization, environmental services utilization, or collection of non-timber forest products, as well as for production forests other than those mentioned above, according to Law 41/1999. for the exploitation of wood and non-timber forest products, as well as the collecting of forest products in the form of wood Due to a change in the licensing regime, the Business License holder will be responsible for paying DR and PSDH after the implementation of Law 11/2020.[28] There are at least four primary points to consider when it comes to potential issues with the DR and PSDH, both of which are viewed as administrative sanctions.[29] First, there is a paradigm change in which the DR and PSDH must wait for 
violations or noncompliance before proceeding with their execution.[30] Second, it gives the perception that policymakers are hesitant to impose sanctions on violators because what is imposed is a must. Third, there are no disincentives for violators of the law, despite the fact that they may previously face criminal penalties. Fourth, administrative sanctions are being repurposed from a legal imposition for disobedience or non-compliance to "simply" requesting that tasks or duties that should have been completed at an earlier stage be completed.[31]

\section{CONCLUSION}

The conclusions in this study were the formulation of DR and PSDH as administrative sanctions, of the four notes, minimizes the aim of administrative sanctions, allows offenders to avoid legal accountability, and allows violators to disobey the law or repeat their crimes in the future. As a result, it is critical to maintain asking business actors to fulfill their DR and PSDH duties while still being susceptible to administrative sanctions in order to solve this problem.

\section{REFERENCES}

[1] R. Danendra, I. G. Ayu, K. Rachmi, and A. K. Jaelani, "Legal Protection of Non Wage Workers Rights After Omnibus Law," Jurisprudentie, vol. 8, no. 13, pp. 8599, 2021.

[2] N. P. Hidayah, "The Implementation of Labor Development Principles According to Job Creation Law as a Reason to Protect Wages Rights," Bestuur, vol. 8, no. 2, pp. 121-128, 2020.

[3] A. L. S. Sudarwanto et al., "POSITION OF FREEDOM OF CONTRACT PRINCIPLE IN FORESTRY PARTNERSHIP POLICY," J. Leg. Ethical Regul. Issues, vol. 24, no. 5, pp. 1-11, 2021.

[4] L. Karjoko et al., "PATENT POLICY ON THE PHARMACEUTICAL SECTOR IN INDONESIA," vol. 23, no. 5, pp. 1-13, 2020.

[5] L. Karjoko, I. G. A. K. R. Handayani, A. S. Sudarwanto, D. W. Winarno, A. K. Jaelani, and W. N. Hanum, "THE CONSEQUENCE OF THE DECISION OF THE CONSTITUTIONAL COURT IN FORESTRY ON THE RECOGNITION OF TRADITIONAL FORESTS IN," J. Leg. Ethical Regul. Issues, vol. 24, no. 5, pp. 1-8, 2021.

[6] M. Pungky and H. Wijaya, "Legislation Impediments in Reorganising Government Bodies in Indonesia," Bestuur, vol. 9, no. 1, pp. 1-16, 2021.

[7] L. C. Lintang, Adriano Martufi, and J.W. Ouwerker, "The Alternative Concepts of Blasphemy Law in Indonesia: Legal Comparison with Ireland and Canada," Bestuur, vol. 8, no. 2, pp. 121-128, 2020.

[8] S. R. Novikasari, D. Q. Ly, and K. Gershaneck, "Taxing Micro, Small and Medium Enterprises in Yogyakarta: Regulation and Compliance," Bestuur, vol. 9, no. 1, 2021.

[9] H. J. Noor, K. Afkar, H. Glaser, and U. G. Mada, "Application of Sanctions Against State Administrative Officials Failing to Implement
Administrative Court Decisions," Bestuur, vol. 9, no. 1, pp. 73-93, 2021.

[10] L. Karjoko, Z. N. Rosidah, and I. G. A. K. R. Handayani, "Refleksi Paradigma Ilmu Pengetahuan Bagi Pembangunan Hukum Pengadaan Tanah Lego," Bestuur, vol. 7, no. 2, pp. 1-14, 2019.

[11] L. Karjoko, "Setting of Plantation Land Area Limitation Based on Social Function Principles of Land Cultivation Rights To Realize Social WelfarePromoting Plantation," J. Din. Huk., vol. 17, no. 1, p. $1,2017$.

[12] A. K. Jaelani, I. G. A. K. R. Handayani, and Isharyanto, "Regulation of Regional Government on Halal Tourism Destinations in West Nusa Tenggara Province after Constitutional Court Decision Number 137/PUU-XIII/2015," Adv. Soc. Sci. Educ. Humanit. Res., vol. 358, no. Icglow, pp. 107-110, 2019.

[13] A. Kadir Jaelani, "IMPLEMENTASI DALUARSA GUGATAN DALAM PUTUSAN PERADILAN TATA USAHA NEGARA DI INDONESIA," Pena Justisia Media Komun. dan Kaji. Huk., vol. 18, no. 2, pp. 56-70, 2019.

[14] A. K. Jaelani, I. G. A. K. R. Handayani, and L. Karjoko, "Development of halal tourism destinations in the Era of regional autonomy in West Nusa Tenggara Province," Int. J. Innov. Creat. Chang., vol. 12, no. 12, pp. 765-774, 2020.

[15] A. K. Jaelani, I. G. A. K. R. Handayani, and L. Karjoko, "Development of tourism based on geographic indication towards to welfare state," Int. J. Adv. Sci. Technol., vol. 29, no. 3 Special Issue, pp. 1227-1234, 2020.

[16] K. Intaniasari, "Gross Split Contract Framework Regulation on the Caring for People," Bestuur, vol. 8, no. 2, p. 96, 2020.

[17] U. K. Mishra and A. Negi, "Transgender and the Right to Employment in India: Analysing the Trajectories of Discrimination," Bestuur, vol. 9, no. 1, pp. 34-43, 2021.

[18] I. G. A. K. R. Handayani, L. Karjoko, and A. K. Jaelani, "Model Pelaksanaan Putusan Mahkamah Konstitusi yang Eksekutabilitas Dalam Pengujian Peraturan Perundang-Undangan di Indonesia," Bestuur, vol. 7, no. 1, pp. 36-46, 2019.

[19] J. D. Ismoyo, "The Model of Management of the Masela Block Based on People's Welfare in Maluku," Bestuur, vol. 8, no. 2, p. 84, 2020.

[20] T. Leonard, E. F. Pakpahan, Heriyati, L. Karjoko, and I. G. A. K. R. Handayani, "Legal review of share ownership in a joint venture company," Int. $J$. Innov. Creat. Chang., vol. 11, no. 8, pp. 332-345, 2020.

[21] S. Akhmaddhian, Hartiwiningsih, and I. G. A. K. R. Handayani, "The government policy of water resources conservation to embodying sustainable development goals: Study in Kuningan, Indonesia," Int. J. Civ. Eng. Technol., vol. 8, no. 12, pp. 419428, 2017.

[22] Soediro, I. G. A. K. R. Handayani, and L. Karjoko, 
"The spatial planning to implement sustainable agricultural land," Int. J. Adv. Sci. Technol., vol. 29, no. 3 Special Issue, pp. 1307-1311, 2020.

[23] E. Suhartini, Hartiwiningsih, I. G. A. K. R. Handayani, and M. Roestamy, "Legal politics and policy setting of wage systems for creating social justice of workers," J. Leg. Ethical Regul. Issues, vol. 22, no. 6, pp. 1-7, 2019.

[24] L. Karjoko, A. Sulitiyono, and I. G. A. K. R. Handayani, "Constructing Corporate Social Responsibility Base on Function Social Principles of Rights to Cultivate," Int. J. Business, Econ. Law, vol. 12, no. 2, pp. 550-551, 2017.

[25] S. A. Estikomah, "Aspek Hukum Import Sampah Plastik," Bestuur, vol. 7, no. 2, p. 41, 2019.

[26] I. Gusti Ayu Ketut Rachmi Handayani, G. Gunarto, A. Mashdurohatun, I. Gusti Putu Diva Awatara, and F. U. Najicha, "Politic of legislation in Indonesia about forestry and the mining activity permit in the forest area of environmental justice," Journal of Engineering and Applied Sciences, vol. 13, no. 6. pp. 1430-1435, 2018.

[27] I. G. A. K. R. Handayani, A. Sulistiyono, T. Leonard, A. Gunardi, and F. U. Najicha, "Environmental management strategy in mining activities in forest area accordance with the based justice in Indonesia," J. Leg. Ethical Regul. Issues, vol. 21, no. 2, 2018.

[28] M. Roestamy, "Model Land Supply for Land Bank to House Application Martin," Bestuur, vol. 7, no. 2, 2019.

[29] C. D. Balenina, "Partisipasi Masyarakat Dalam Pengelolaan Desa Sampah Mandiri Di Desa Kalisoro, Tawangmangu, Kabupaten Karanganyar," Bestuur, vol. 7, no. 1, pp. 26-35, 2019.

[30] W. N. Hanum, "Setting of Earth Oil Management in Old Wells Based on the Principle Social Justice," Bestuur, vol. 8, no. 2, p. 70, 2020.

[31] P. Erina and A. M. Yanis, "Reconstruction of Mining Policies on Justice in Lampung Province," Bestuur, vol. 8, no. 2, p. 139, 2020. 